\title{
Phaffia, a New Yeast Genus in the Deuteromycotina (Blastomycetes)
}

\author{
M. W. MILLER, MINORU YONEYAMA, ${ }^{1}$ AND MASAMI SONEDA ${ }^{2}$ \\ Department of Food Science and Technology, University of California, Davis, California 95616
}

\begin{abstract}
A description is given of a new yeast genus, Phaffia, represented by $P$. rhodozyma sp. nov., to accomodate nine yeast strains isolated in Japan and one in Alaska, all from exudates of deciduous trees. The type strain of $P$. rhodozyma is UCD (FS\&T) 67-210 (= ATCC 24202 = CBS 5905). Phaffia, named in recognition of the contributions of Herman Jan Phaff to yeast taxonomy and ecology, is a carotenoid-producing, fermentative yeast of the Deuteromycotina (Blastomycetes), whose properties indicate a basidiomycetous origin. A comparison is made between Phaffia and other yeast genera to which it might be related.
\end{abstract}

In surveys of yeasts in tree exudates (slime fluxes) in Japan and in the Pacific Northwest of North America (16), we isolated 10 similar yeast strains that belong to a new species which represents a new genus. This yeast produces carotenoid pigments, reproduces vegetatively by budding, and lacks, as far as we have been able to determine, a sexual life cycle. It could not be accommodated in the genus Rhodotorula Harrison because species in that genus are nonfermentative, whereas the isolates from tree exudates ferment several sugars. In an earlier publication (16), this yeast was tentatively named Rhodozyma montanae. However, a Latin diagnosis, as required by the rules of the International Code of Botanical Nomenclature, was not given, and this binomial is therefore a nomen nudum. The intent of this paper is to give a complete description, to discuss the taxonomic relationships of the new organism, and to provide it with a validly published name.

\section{MATERIALS AND METHODS}

Samples of exudates were collected in new plastic vials or bags. Usually within 6 to $18 \mathrm{~h}$ after collection, a loopful of the slimy exudate was streaked directly on $5 \%$ malt agar acidified with hydrochloric acid to $\mathrm{pH}$ 3.7. If the sample was in a dehydrated condition, it was removed from the tree with a specially made chisel sterilized in alcohol. It was then rehydrated with a small amount of sterile water for a suitable length of time before streaking. The inoculated plates were stored at room temperature ranging from about 15 to $25 \mathrm{C}$. On most of the plates, relatively few fungi appeared, but many of the samples yielded significant numbers of bacterial colonies in spite of the low $\mathrm{pH}$ of malt agar. The plates were inspected with a dissecting microscope after 3 to 6

${ }^{1}$ Present address: Biological Institute, Osaka Shin-Ai Womens College, Osaka, Japan.

${ }^{2}$ Present address: Department of Food Hygienic Science, Tokyo Kasei University, Tokyo, Japan. days of growth, and a visual estimate was made of the proportion of the various colony types. One colony of each type of yeast was picked for purification, but bacterial colonies were not isolated. Purification of the isolates was accomplished by two successive platings on $5 \%$ malt agar. The 10 strains and their isolation sources are listed in Table 1.

In the identification of the isolates, the standard methods currently employed in yeast taxonomy (28) were used. Deoxyribonucleic acid (DNA) extraction and purification were done by a combination of the procedures of Marmur (12) and Bernardi et al. (4). The moles percent guanine plus cytosine $(G+C)$ of the DNA was calculated from buoyant density values in cesium chloride $(21,26)$, based on three separate determinations. Micrococcus lysodeikticus DNA, with a buoyant density of $1.7311 \mathrm{~g} / \mathrm{ml}$, was used as a reference. The buoyant density of the $M$. lysodeikticus DNA was derived from comparison with Escherichia coli K-12 DNA, whose buoyant density was taken to be 1.7100 . Mating attempts were by the procedures of Wickerham and Burton (32) and van der Walt $(29,31)$. The scanning and transmission electron micrographs were taken by the method of Talens et al. (27).

\section{RESULTS}

In recognition of the outstanding and continuing contributions by Herman Jan Phaff to the fields of yeast taxonomy and ecology, we propose the name Phaffia for this new genus. It is represented by a single species. Phaffia rhodozyma sp. nov., and is characterized below.

The vegetative cell wall is multilayered and forms a bud in a manner characteristic of heterobasidiomycetous yeasts (8) (Fig. 1). Chlamydospores germinated by budding (Fig. 2), but a definitive promycelium and sporidial formation did not occur. Attempts to mate the various strains in the hope of observing subsequent dikaryotic mycelium and teliospore formation were unsuccessful. Consequently, the new 
TABLE 1. Sources and localities of isolation of strains of Phaffia rhodozyma

\begin{tabular}{|c|c|c|c|c|}
\hline Strain & Source & Locality & $\begin{array}{l}\text { Elevation } \\
\quad(\mathrm{m})\end{array}$ & $\begin{array}{c}\text { Fre- } \\
\text { quency }\end{array}$ \\
\hline $67-202$ & Cornus brachypoda & Hiroshima, Kario-yama & 1,200 & $\gg 300$ \\
\hline $67-203$ & C. A. Mey & & & \\
\hline \multicolumn{5}{|l|}{ H11-A } \\
\hline $67-210$ & $\begin{array}{l}\text { Fagus crenata } \\
\text { Blume }\end{array}$ & Kyoto, Uchimi-yama & 1,200 & Few \\
\hline $67-383$ & $\begin{array}{l}\text { Alnus japonica } \\
\text { (Thunb.) Steud. }\end{array}$ & Kiso, Shinkai & 1,600 & 300 \\
\hline $67-385$ & $\begin{array}{l}\text { Betula tauschii } \\
\text { Koidz. }\end{array}$ & Kiso, Shinkai & 1,600 & $>300$ \\
\hline $67-484$ & $\begin{array}{l}\text { B. maximowicziana } \\
\text { Regel }\end{array}$ & Yamagata, Yatani & 1,000 & 15 \\
\hline $68-653 \mathrm{C}$ & $\begin{array}{l}\text { B. papyrifera } \\
\text { Marsh }\end{array}$ & Rainbow Lake, Alaska & 100 & \pm 30 \\
\hline $316 \mathrm{~A}$ & Betula sp. & Fuji-yama & 750 & $>300$ \\
\hline 612 & $\begin{array}{l}\text { Ulmus japonica } \\
\text { (Rehd.) Sarg. }\end{array}$ & Hokkaido, Yamabe & 430 & $-b$ \\
\hline
\end{tabular}

a Approximate number of colonies per plate inoculated with one loopful of flux material.

${ }^{b}$ Not noted.

yeast genus is placed in the Deuteromycotina in the form order Blastomycetes.

\section{Latin diagnosis}

Phaffia Miller, Yoneyama, et Soneda (Blastomycetes), gen. nov.

Cellulae vegetativae ellipsoideae, singulae, binae, interdum catenatae. Pigmenta carotinoidea (praecipue astaxanthina, $\beta$-carotina quoque) formantur, cellularum ponderibus sandaracoidum aut salmonis rubrum colorem dans. Mycelium absens, sed pseudomycelium rudis formari potest. Chlamydosporae formantur. Velum supra media liquida formatur.

Fermentatio praesens.

Materia amyloidea formantur ( $\mathrm{pH}$ sejuncte).

Typus: Phaffia rhodozyma Miller, Yoneyama, et Soneda.

Genus characteristics. Vegetative cells are ellipsoidal and occur singly, in pairs, and occasionally in short chains. Carotenoid pigments are synthesized (mainly astaxanthin and a minor proportion of $\beta$-carotene) which give cells en masse an orange to salmon-red color. True mycelium is absent, but a rudimentary pseudomycelium may be present. Chlamydospores are formed. A pellicle is formed on liquid media.

Fermentative ability present.

Starchlike compounds are formed (synthesis is $\mathrm{pH}$ independent).

Type of the genus: Phaffia rhodozyma Miller, Yoneyama, et Soneda.

\section{Latin diagnosis.}

Phaffia rhodozyma sp. nov.

In extracto malti, post tres dies, cellulae elliposoideae $(3.8-7.5) \times(5.5-10.5) \mu \mathrm{m}$, singulae, binae, interdum catenatae. Frequente ibidem gemmant. Chlamydosporae rotundae cum granibus fulgentibus post plures dies formari possunt. Annulus et velum tenue cum sedimentum parvum formantur. Post unum mensem, annulus sandaracoidus crasusque, velum tenuis aut insulae et medium sedimentum praesenta sunt.

In agaro extractis malti, post unum mensem, cultura lineamentosa sandaracoida vel salmonis rubra, superficiei apiatae vel paene levis, nitida vel semi-hebetis, mollis et sectionis laxe convexae vel convexae est; ora paene illibata vel libulata.

In agaro farinae maïs (Dalmau), portio aeria interdum oram inequalem habet; sub laminella vitri, interdum cristae cellularum pseudomycelii rudis, ex paucis cellulis formatae, praesentes sunt. Mycelium non formatur.

Glucosum medie, maltosum, saccharum et raffinosum exigue fermentantur; galactosum et melibiosum non fermentantur.

Glucosum, maltosum, saccharum, cellobiosum, trehalosum, raffinosum, melezitosum, amylum (lente aut -), D-xylosum (lente), L-arabinosum, ethanolum, D-mannitolum (lente), $\alpha$ methyl-glucosidum (lente aut -), salicinum exigue, glucono- $\delta$-lactonum, calcium-2-ketogluconatum, kalium-5-ketogluconatum (lente), acidium lacticum (lente) et acidum succinicum assimilantur, at non galactosum, L-sorbosum, lactosum, melibiosum, inulinum, D-arabinosum, D-ribosum, L-rhamnosum, methanolum, glycerolum, erythritolum, ribitolum, galactitolum, D-glucitolum, acidum citricum et meso-inositolum.

Kalium nitricum, ethylaminum non assimilantur. 

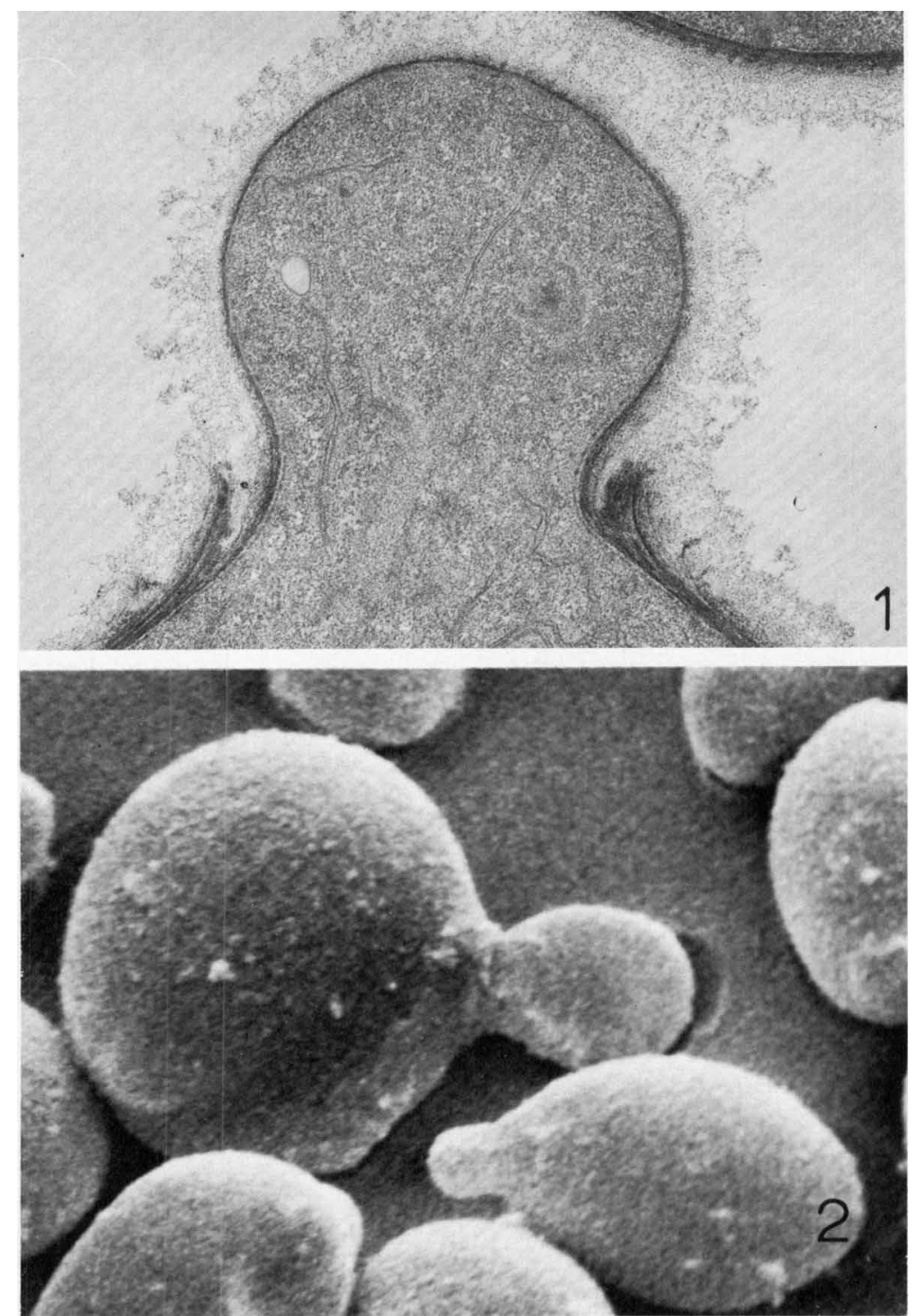

FIG. 1. Transmission electron micrograph of Phaffia rhodozyma UCD (FS\&T) 67-210 revealing the multilayered nature of the cell wall. Remnants of the outer wall layers form a collar as the new bud emerges while the inner layer is continuous. Also note the capsular material (electron-transparent area) surrounding the cell. $\times 41,000$.

Fig. 2. Scanning electron micrograph of Phaffia rhodozyma UCD (FS\&T) 67-210 showing a budding chlamydospore and a budding vegetative cell. The chlamydospore is easily distinguished by its spheroidal shape and large size. Granular appearance of the cell surfaces is due to the presence of capsular material. $\times 6,500$.

Ad crescentiam biotinum necessarium est. Mol\% G+C: $48.3 \pm 0.18$.

Typus: stirps UCD (FS\&T) 67-210, ex Fagus crenatae isolata. In collectione zymotica Centraalbureau voor Schimmelcultures, Delphi Batavorum sub No. 5905 deposita est.
Species characteristics. (i) Growth in malt extract. After 3 days, the cells are ellipsoidal 3.8 to 7.5 by 5.5 to $10.5 \mu \mathrm{m}$, occurring singly, in pairs, or occasionally in short chains. Budding occurs frequently at the same site. Spheroidal chlamydospores with refractile granules may be formed after several days. A thin ring and 
pellicle are formed, and there is little sediment. After 1 month, there are a thick, orange ring, a thin pellicle or islets, and a moderate amount of sediment.

(ii) Growth on malt extract agar. After 1 month, the streak culture is orange- to salmonred, punctilate to nearly smooth, glossy to semidull, soft and broadly convex to convex in cross section; the border is lobulate to nearly entire.

(iii) Dalmau plate culture on corn meal agar. In the aerobic portion, the border is occasionally irregular; under the cover slip, there is an occasional tuft of cells or rudimentary pseudomycelium consisting of limited numbers of cells in a chain. No true mycelium is formed.

(iv) Others. Fermentation: D-Glucose, moderate (a full tube of gas is formed in 5 to 11 days); maltose, weak; sucrose, weak; raffinose, weak. D-Galactose and melibiose are not fermented.

Assimilation of carbon compounds: D-Glucose, +; D-galactose, -; L-sorbose, -; maltose, + ; sucrose, +; cellobiose, +; trehalose, +; lactose, -; melibiose, -; raffinose, +; melezitose, +; inulin, -; soluble starch, + (latent) or -; Dxylose, + (latent); L-arabinose, +; D-arabinose, -; D-ribose, -; L-rhamnose, -; ethanol, + (latent) or -; methanol, --; glycerol, -; erythritol, -; ribitol, -, galactitol, -; D-mannitol, + (latent); D-glucitol, - ; alpha-methyl-D-glucoside, + (latent or -; salicin, + (weak); glucono- $\delta$ lactone, +; calcium-2-ketogluconate, +; potassium-5-ketogluconate, + (latent); DL-lactate, + (latent); succinate, +; citrate, -; and mesoinositol, - .

Assimilation of nitrogen compounds: Potassium nitrate, -; ethylamine, -

Growth in vitamin-free medium: Absent. Biotin is required for growth.

Growth on $50 \%$ (wt/wt) glucose-yeast extract agar: Absent.

Growth on $10 \%$ sodium chloride-yeast extract agar: Absent.

Temperature range of growth: 0 to $27 \mathrm{C}$.

Acid formation on chalk agar: Weak.

Synthesis of starchlike compounds: Positive (pH independent).

Gelatin liquefaction: Weak.

Casein hydrolysis: Absent.

Hydrolysis of urea: Positive.

Lipolytic activity: Absent.

Growth in the presence of $0.1 \mu \mathrm{g}$ of cycloheximide per ml: Absent.

Synthesis of carotenoid pigments: Positive (approximately $85 \%$ is astaxanthin).

$\mathrm{Mol} \% \mathrm{G}+\mathrm{C}: 48.3 \pm 0.18$.

(v) Type. The type strain UCD (FS\&T) 67210 , isolated from Fagus crenata at Uchimi- yama (Kyoto Prefecture) at an elevation of $1,200 \mathrm{~m}$, has been deposited in the collection of the Yeast Division of the Centraalbureau voor Schimmelcultures in Delft, The Netherlands as CBS 5905 and in the American Type Culture Collection, Rockville Md., as ATCC 24202.

(vi) Habitat. Ten strains have been isolated. All came from exudates (slime fluxes) of deciduous trees (Table 1).

\section{DISCUSSION}

Attempts to disclose a sexual life cycle in Phaffia rhodozyma were unsuccessful. The various isolates were mixed in all possible combinations on media proven successful for sporulation or mating of other species, and heat treatments of cells showed no resistant stages and no mated generations leading to dikaryotic mycelium. The chlamydospores show a morphological similarity with those of Aessosporon. Upon germination of the chlamydospore, vegetative cells are produced by budding. However, these cells could not be construed in any definitive manner as promycelia with sporidia similar to those described by van der Walt (30) for Aessosporon. Thus, no basis exists for regarding these chlamydospores as gonotoconts or their buds as the haploid generation. Nuclear stains were inconclusive as to a diploidization at any stage of growth. Transmission electron micrographs revealed but a single nucleus during all phases of growth.

Criteria that may be used for imperfect yeasts as indicators of an ascomycetous or basidiomycetous origin are the ability to form ballistospores (9), the ability to synthesize carotenoid pigments (not known to occur in ascogenous yeasts), the base composition of DNA acid expressed as moles percent $\mathrm{G}+\mathrm{C}(14,24,25)$, the cell wall structure and the mode of bud formation (8), and the nature of the polysaccharides that make up the capsules of encapsulated yeasts (17). In connection with the latter criterion, the acidic heteropolysaccharides of Cryptococcus and of some species of Trichosporon relate these yeasts to the Tremellaceae of the Ustilaginales (Basidiomycotina). The linear $\beta$ $(1 \rightarrow 3)$ - and $\beta$-( $1 \rightarrow 4)$-linked mannan of Rhodotorula is unknown among ascomycetous yeasts.

Criteria for determining the phylogenetic origin of Phaffia rhodozyma were as follows. The $\mathrm{G}+\mathrm{C}$ value of $48.3 \pm 0.18 \mathrm{~mol} \%$ was not helpful since it falls in the "grey zone," being at the upper limit of ascomycetous yeasts (approximate range, 30 to $50 \mathrm{~mol} \% \mathrm{G}+\mathrm{C}$ ) and the lower limit of basidiomycetous yeasts (approximate range, 50 to $70 \mathrm{~mol} \%$ ) (13). The cell wall polysaccharides contain a high proportion of $\alpha-1,3$ - 
glucan (pseudonigeran), which is found in basidiomycetous yeasts as well as in the nonbudding, ascomycetous genera Schizosaccharomyces and Endomyces (2; Melvin T. Meyer, Ph.D. thesis, Univ. of California, Davis, 1975). The ability of $P$. rhodozyma to hydrolyze urea is more commonly found among basidiomycetous than among ascomycetous yeasts $(1,22)$. $P$. rhodozyma contains carotenoid pigments, which are not found in ascogenous yeasts. The most conclusive evidence of the phylogenetic origin of Phaffia is the disclosure of a multilayered cell wall near the area of repeated bud formation. This budding mechanism is similar to that of heterobasidiomycetous yeasts (8). Bud scars shown by transmission and scanning electron microscopy are also characteristic of this origin.

In recent years, several asporogenous yeast genera of basidiomycetous affinity have been shown to have sexual cycles. Banno (3) was the first to discover Rhodotorula glutinis strains that mated. The zygotes produced a dikaryotic mycelium with clamp connections and gave rise to teliospores. The germination of these spores to a septate promycelium and budding spores (sporidia) confirmed the basidiomycetous nature of these yeasts. He established the genus Rhodosporidium (Ustilaginales) to accommodate the perfect stage. Banno's attempts to find a sexual cycle in Sporobolomyces were unsuccessful. Kluyver and van Niel (7) suggested a basidiomycetous origin for Sporoblomyces since its spores were released by the same drop-secretion mechanism that is responsible for the discharge of basidiospores. Sainclivier (18-20) postulated that the ballistospores of Sporobolomyces were sexual basidiospores. However, van der Walt (30) was successful in inducing a single strain of Sporobolomyces salmonicolor to form teliospores which germinated, usually by a nonseptate promycelium bearing two to four sporidia. He described Aessosporon (Tilletiaceae) to accommodate these sexual forms. Thus, while suggested over 50 years ago, the basidiomycetous origins of several yeast genera have been confirmed only recently by the demonstration of their sexual life cycles. Thus far, none of the yeasts that produce carotenoid pigments are fermentative. Only some species of Leucosporidium and of Filobasidium (Ustilaginales), genera containing only nonpigmented species, are fermentative.

Upon comparison of Phaffia with other yeast genera, there are a number of differences that necessitate establishment of a new genus. The ability to ferment sugars is not shared by any other genus of carotenoid-producing yeasts, and this property sharply differentiates Phaffia from those yeasts. Equally distinctive is the production of astaxanthin, which represents ca. $85 \%$ of the carotenoid pigments produced by Phaffia (A. G. Andrewes, H. J. Phaff, and M. P. Starr, Phytochemistry, in press) and is not known to be produced by yeasts of other genera. Conversely, torulene and torularhodin, which are known to be the main carotenoid pigments of Rhodotorula and of other red-pigmented, carotenoid-producing yeasts (23), were not found in Phaffia. Astaxanthin is commonly associated with marine crustaceae (i.e., shrimp, crab, lobster, etc.), although it is known to be produced by some plants and algae and has also been reported in a few basidiomycetous fungi (J. L. Fiasson, Ph.D. thesis, Univ. of Lyon, Lyon, France, 1968).

Specific criteria differentiating Phaffia from other genera are: the inability to form ballistospores (positive for Sporobolomyces, Sporidiobolus, and Aessosporon); the absence of an observed sexual cycle (positive for Rhodosporodium, Aessosporon, and Sporidiobolus); and fermentative ability (negative for Cryptococcus and Rhodotorula). A comparison was made also with Rhodomyces dendrorheus, a yeastlike organism superficially described by Ludwig (10, 11). Other than color and source of isolation (red flux of Betula sp.), we could determine no similarity. Apparently Ludwig never isolated this organism in pure culture. Saccardo (17) placed Rhodomyces in synonymy with Monilia.

In summary, the properties that make Phaffia unique among the genera with which it can be compared are the production of carotenoid pigments, of which astaxanthin is the principal component, and the ability to ferment sugars, a property not shared by any other carotenoidproducing yeast.

\section{ACKNOWLEDGMENTS}

This research was supported by grants from the National Science Foundation (GF-258) and the Japanese Society for the Promotion of Science under the U.S.-Japan Cooperative Science Program, and by Public Health Service grant GM16307-05 from the National Institute of General Medical Sciences.

The capable technical assistance of Ellen Barker-Johnson and Mary Miranda is gratefully acknowledged. Special thanks are due to Stephen Douglass for determining the DNA base compositions and to Marc-André Lachance for his assistance with the Latin diagnoses.

\section{REPRINT REQUESTS}

Address reprint requests to: $M$. W. Miller, Department of Food Science and Technology, University of California, Davis, Calif. 95616 .

\section{LITERATURE CITED}

1. Abadie, F. 1967. L'Urease chez les levures. Ann. Inst. Pasteur Paris 113:791-813. 
2. Bacon, J. S. D., D. Jones, V. C. Farmer, and D. M. Webley. 1968. The occurrence of $\alpha(1-3)$ glucan in Cryptococcus, Schizosaccharomyces and Polysporus species, and its hydrolysis by a Streptomyces culture filtrate lysing cell walls of Cryptococcus. Biochim. Biophys. Acta 158:313-315.

3. Banno, I. 1967. Studies on the sexuality of Rhodotorula. J. Gen. Appl. Microbiol. 13:167-196.

4. Bernardi, G., M. Foures, G. Piperno, and P. P. Slonimski. 1970. Mitochondrial DNAs from respiratory-sufficient and cytoplasmic respiratory-deficient mutants of yeast. J. Mol. Biol. 48:23-42.

5. de Miranda, L. R. 1972. Filobasidium capsuligenum nov. comb. Antonie van Leeuwenhoek J. Microbiol. Serol. 38:91-99.

6. Fell, J. W., A. C. Statzell, I. L. Hunter, and H. J. Phaff. 1969. Leucosporidium gen. n., the heterobasidiomycetous stage of several yeasts of the genus Candida. Antonie van Leeuwenhoek J. Microbiol. Serol. 35:433-462.

7. Kluyver, A. J., and C. B. van Niel. 1924. Uber Spiegelbilder erzeugende Hefearten und die neue Hefengattung Sporobolomyces. Zentralbl. Bakteriol. Parasitenkd. Infektionskr. Hyg. Abt. 2 63:1-20.

8. Kreger-van Rij, N. J. W., and M. Veenhuis. 1971. A comparative study of the cell wall structure of basidiomycetous and related yeasts. J. Gen. Microbiol. 68:87-95.

9. Lodder, J. 1970. General classification of the yeasts, p. 1-33. In J. Lodder (ed.), The yeasts - a taxonomic study. North Holland Publishing Co., Amsterdam.

10. Ludwig, F. 1891. Der Milch- und Rothfluss der Bäume und ihre Urheber. Vorlaufige Mitteilung. Centrbl. Bakteriol. 10:10-13.

11. Ludwig, F. 1896. Sur les organismes des ecoulements des arbres. Rev. Mycologique, Toulouse 18:45-57, 114-123.

12. Marmur, J. 1961. A procedure for the isolation of DNA from microorganisms. J. Mol. Biol. 3:208-218.

13. Meyer, S. A., and H. J. Phaff. 1970. Taxonomic significance of the DNA base composition in yeasts. Spectrum 1:1-29.

14. Nakase, T., and K. Komagata. 1968. Taxonomic significance of base composition of yeast DNA. J. Gen. Appl. Microbiol. 14:345-357.

15. Phaff, H. J. 1971. Structure and biosynthesis of the yeast cell envelope, p. 135-210. In A. H. Rose and J. S. Harrison (ed.), The yeasts, vol. 2. Physiology and biochemistry of yeasts. Academic Press Inc., London.

16. Phaff, H. J., M. W. Miller, M. Yoneyama, and $M$. Soneda. 1972. A comparative study of the yeast florae associated with trees on the Japanese Islands and on the West Coast of North America, p. 759-774. In G. Terui (ed.), Proc. IV IFS: Ferment. Technol. To- day, Kyoto. Society of Fermentation Technology, Osaka.

17. Saccardo, P. A. 1892. Sylloge fungorum, omnium hucusone, vol. X. Supplementum Pars II, p. 518. P. A. Saccardo, Pavia, Italy.

18. Sainclivier, M. 1951. Etude caryologique des Sporobolomyces. Bull. Soc. Bot. Fr. 98:165-168.

19. Sainclivier, M. 1951. Arguments caryologiques sur les Sporobolomyces. Bull. Soc. Bot. Fr. 98:255-258.

20. Sainclivier, M. 1952. Caryologie des Sporobolomyces. Bull. Soc. Bot. Fr. 99:147-149.

21. Schildkraut, C. L., J. Marmur, and P. Doty. 1962. Determination of the base composition of deoxyribonucleic acid from its buoyant density in $\mathrm{CsCl}$. J. Mol. Biol. 4:430-433.

22. Seeliger, H. P. R. 1956. Use of a urease test for the screening and identification of cryptococci. J. Bacteriol. 72:127-131.

23. Simpson, K. L., C. O. Chichester, and H. J. Phaff. 1970. Carotenoid pigments of yeast, p. 493-516. In A. H. Rose and J. S. Harrison (ed.), The yeasts, vol. 2. Physiology and biochemistry of yeasts. Academic Press Inc., London.

24. Stenderup, A., and A. Leth Bak. 1968. Deoxyribonucleic acid base composition of some species within the genus Candida. J. Gen. Microbiol. 52:231-236.

25. Storck, R., C. J. Alexopoulos, and H. J. Phaff. 1969 Nucleotide composition of deoxyribonucleic acid of some species of Cryptococcus, Rhodotorula, and Sporoblomyces. J. Bacteriol. 98:1069-1072.

26. Szybalski, W. 1968 . Use of cesium sulfate for equilibrium density gradient centrifugation, p. 330-360. In L. Grossman and K. Moldavic (ed.), Methods in enzymology, vol. 12B. Academic Press Inc., New York.

27. Talens, L. T., M. Miranda, and M. W. Miller. 1973. Electron micrography of bud formation in Metschnikowia krissii. J. Bacteriol. 114:413-423.

28. van der Walt, J. P. 1970 . Criteria and methods used in classification, p. 34-113. In J. Lodder (ed.), The yeasts - a taxonomic study. North Holland Publ. Co., Amsterdam.

29. van der Walt, J. P. 1970. Ploidy differences in Cryptococcus albidus. Mycopathol. Mycol. Appl. 42:17-24.

30. van der Walt, J. P. 1970. The perfect and imperfect states of Sporobolomyces salminicolor. Antonie van Leeuwenhoek J. Microbiol. Serol. 36:49-55.

31. van der Walt, J. P. 1973. The perfect state of Torulopsis magnoliae. Antonie van Leeuwenhoek J. Microbiol. Serol. 39:635-647.

32. Wickerham, L. J., and K. A. Burton. 1954. A simple technique for obtaining mating types in heterothallic diploid yeasts, with special reference to their uses in the genus Hansenula. J. Bacteriol. 67:303-308. 